\title{
Piil Pesenggiri: \\ A Concept of Political Power in Lampung Culture
}

\author{
Robi Cahyadi Kurniawan`
}

\begin{abstract}
Power is the main focus of political science, so far the concept of power that exists in Indonesia comes from the conception of western cultural thought, especially Europe, which influenced the thinking of the thinkers of the era of Greece, Rome, and medieval Europe. After the reform and era after 2000, Indonesian thinkers tried to offer the concept of power based on local wisdom based on local culture. So that emerged local concepts of politics and power. This paper attempts to relate the principles of the local culture of Lampung piil pesenggiri in the context of contemporary politics today, especially in the election, including things mystical. The method used in this research/ writing by using qualitative methods with secondary data sources and literature study. The result in the level of the concept piil pesenggiri be ideal, but the level is still questionable practice.
\end{abstract}

\section{Keywords:}

power; Lampung culture; piil pesenggiri; mystical politics.

\begin{abstract}
Abstrak
Kekuasaan merupakan fokus utama dari ilmu politik, selama ini konsepsi kekuasaan yang ada di Indonesia berasal dari konsepsi pemikiran budaya barat khususnya Eropa, yang di pengaruhi pemikiran para pemikir era Yunani, Romawi, dan Eropa Abad Pertengahan. Pasca reformasi dan era setelah tahun 2000, pemikirpemikir Indonesia mencoba menawarkan konsep kekuasaan yang berbasiskan kearifan lokal dengan berbasiskan budaya lokal. Sehingga muncul konsep-konsep lokal tentang politik dan kekuasaan. Tulisan ini mencoba mengkaitkan prinsip-prinsip budaya lokal Lampung Piil Pesenggiri dalam konteks politik kontemporer dewasa ini khususnya dalam pemilukada, termasuk hal-hal yang berbau mistis. Metode yang dipakai dalam penelitian /tulisan ini dengan menggunakan metode kualitatif dengan sumber data sekunder dan studi kepustakaan. Hasilnya dalam tataran konsep Piil Pesenggiri menjadi ideal, tetapi dalam tataran praktek masih dipertanyakan.
\end{abstract}

\section{Kata kunci :}

kekuasaan; budaya Lampung; piil pesenggiri; mistis politik.

\section{Introduction}

Power is the main focus of the study of political science, because power is a key aspect of political science, all matters of politics are about power (Heywood, 2004: 121). The definition of power is the ability of a person or group of people to influence others to follow the wishes or wills of a person or group of people

\footnotetext{
- Governmental Department, Political and Sosial Science Faculty, University of Lampung Email: robicahyadi9@gmail.com
} 
(Budiardjo, 2008: 18). Robert Dahl (1985) sees power as a relationship between one person and another. Power is generally defined as the ability to use sources of influence to influence the behavior of others so that others behave in accordance with the will of the parties that influence, more narrowly political power is the ability to use the sources of influence to influence the process of making and execution of political decisions so that Decisions that benefit him, his group or society in general (Surbakti, 1992: 58).

During this time the concept of power in Indonesia is strongly influenced by Western thinkers, starting from Ancient Greek thought, Roman and medieval (Schmandt, 2002: 3445). Political science has a long history that began from the time of the ancient Greeks, in its development according to George B. De Huzar (in Darmawan, 2015: 4), political science is divided into three periods. The first time was in Ancient Greece, the ancient Greeks had used the term "Polytheia", which literally meant a group of politically incorporated people in organizations that not only referred to the political community but also the whole part of people's lives. (Darmawan, 2015: 4).

The second period is in Roman times, the Middle Ages, and the Renaissance period. In the Roman period, the study of political science was more concerned with the study of law, while in the middle of the study of politics more concerned with the study of the relationship between state and religion, in the Renaissance period more discussing the separation between politics and ethics. The third period of the modern era, characterized by many approaches in political science. The number of approaches in political science can be divided into two trends in a large group of political scientists. First, a group of political scientists who emphasize attention to legal and institutional phenomena. Second, a collection of political scientists interested in the study of political behavior and processes (Darmawan, 2015: 5).
Since the reign of reforms that began in 1997-1999, there was a change of thinking paradigm in the Indonesian political context, resulting in direct election in 2005, and with all its dynamics emerged various rules of law supporting the implementation of regional autonomy as a tandem of direct election. Direct elections proved to have a negative side of the face of democracy is raised, in addition to the political emergence of the high cost (cost politics), candidates are not credible, head of the region dealing with corruption and civil servants who are not neutral and the people who play by the circulation of money politics.

This phenomenon raises the concerns of various parties (academics and democracy activists), namely whether the democracy that has been going on in Indonesia has touched its substance, or the content of the meaning of democracy, which is simply interpreted as a process of, for and by the people, citing opinions Aristotle democracy aims for the welfare and prosperity of the people. Democracy in Indonesia is not more than procedural, which means seeking power with the election mechanism with the winner of the most votes, one man one vote, regardless of whether the candidate elected leader was credible, competent, not corrupt or noble.

In some ways, western democracy can not answer the above problems, so that thinkers in Indonesia try to find new alternatives in the context of democracy by linking it with Indonesian culture, especially local culture.

This paper attempts to examine the concepts, definitions, patterns of local democracy relating to power outside of western thought, especially in the context of the local culture of Lampung. Lampung in the local context, the author tries to elaborate the principles of local culture and some of the principles of life.

\section{Methods}

This study uses qualitative research methods used to examine the condition of 
natural objects, where researchers are key instruments, data analysis is inductive / qualitative, qualitative research results are more concerned with the meaning than generalization (Sugiyono, 2006: 9-10). The observation in this study used literacy studies or literature studies; reviewing the results of previous research sourced from the books and journals related to the object of research.

Sources of data in this paper or research is to use secondary data, in this study sourced from materials supporting libraries and or information obtained through third parties who are considered to have something to do with the problem under study; Such as books, journals, documents and rules of invitation relating to this research. In other words, data collection techniques in writing / research is through literature.

\section{Discussion}

\section{Conception and Relationship of Power}

Some concepts are closely related to the concept of power is the concept of influence, persuasion, coersion, force and authority. Influence is the ability to influence others to change their attitudes and behavior voluntarily. Persuasion is the ability to convince others with the argument to do something, manipulation is the use of influence, in which case the affected do not realize that his behavior actually obeys the desire of the holder of power. Coercion is a demonstration of power or threat of coercion done by a person or group of people against another party in order to act and behave in accordance with the will of the powers, including the attitudes and behavior contrary to the will is influenced, for example, the arrest by the police and military interrogation. Force is the use of physical pressure, such as restricting freedom, cause pain or limit the biological needs of the other person to do something. (Surbakti, 1992: 57).

Power can be managed in two ways: coercive or by using coercion and consensual or without coercion, the use of power by coercive means can be divided into three forms of physical coercive, coercive economic and coercive psychic, while the management of power in a consensual way related to the pattern of political leadership, Which is initiative, manage and protective (Darmawan, 2015: 23-25).

Physical coercion is a power that uses brutal coercion, by killing, imprisoning or punishment related to it. Economic coercive is the power that uses coercion by taking shape by not providing the means to save his life. Coercive psychic is power by using coercion through role play and power by the authorities, usually done by a coercive and authoritarian ruler. The initiator is the initiating leadership by taking political action that inspires his followers to follow his actions, or associate themselves with the leader. Managing is defined as managing leadership by maintaining the order of things that have been built, also called the conservator by emphasizing the line of political action in accordance with the wishes of his followers. Protective is the leadership that protects and provides security for its followers (Darmawan, 2015: 23-25).

Power relationships contain three elements that include the purpose, the way the use of sources of influence and the results of the use of sources of influence, so that power relations have certain characteristics as a result of the existence of three elements are: first- power is the relationship between man; second- the power holder affects the other; third- the holder of power may be an individual or group or organization or government; fourth- the target of the affected power may be the individual or group or organization or government; fifth- a party with a source of power does not necessarily have power because it depends on its ability to use resources effectively; sixth- the use of sources of power may involve coercion, consensus or a combination of two; seventh- It depends on 
the moral perspective that is used whether the goal to be achieved is good or bad; eighth- The results of the use of those sources of influence can benefit the whole society or benefit a small group of people depending on the distribution of power; ninth- Ideally sources of power are used for the maslahat of the general public not for the benefit of a minority of society; the tenth- Political power is the use of sources of influence to influence the political process (Surbakti, 1992: 58-59).

Power by Andrain and Putnam (in Surbakti 1992: 59-64) has six potential and actual dimensions, positive and negative, consensus and coercion, position and personality, implicit and explicit, direct and indirect. The power in its implementation has three main issues that become observations in political science, namely how power is exercised, how power is distributed, and why a particular person or group has more power than other people or groups in certain circumstances, Four factors that need to be studied in the implementation of power, namely; the form and number of sources, the source distribution, when people and groups use resources, and the results of the use of power sources (Surbakti, 1992: 64).

According to Charles F. Andrain (in Surbakti, 1992: 74-75), political scientists describe the distribution of power in the form of three models, namely; Model of the ruling elite, pluralist model, and populist model. The elite model is power held by a small group of people who govern called elite. The pluralist model is power held by various social groups in society and various institutions within government. The populist model is the power held by individual citizens.

The assumption underlying the pluralist model of the distribution of power is that each individual belongs to one or more specific social or social groups in accordance with the ideological and cultural aspirations and interests of the economy, according to the pluralist model of power in society will be distributed relatively evenly among the various Organizations and interest groups; Government in this model acts as an arena of competition and compromise among various social groups and forces in society (Surbakti, 1992: 77-78).

The assumption underlying the populist or populist model is democracy, meaning the participation of individual citizens in the process of making and implementing political decisions, which will clearly affect the joints of individual and social life in society (Surbakti 1992: 78).

\section{Power in Javanese Culture}

Indonesia has a different power concept with western-derived literature, one of which is the conception of Javanese power. The Javanese conception of power differs radically from a concept that has developed in the west since the medieval ages, from this distinction logically resulting in striking differences in views of the way political and historical work (Anderson 2000: 42). Javanese traditional political culture is a very complex phenomenon, in this culture there is an incomplete mixing with elements of Brahmanism (Hinduism), Buddhism and Islam and the influx of western influences.Java's subordination to western political, economic and cultural domination, especially in the last hundred years, has moved the process of decrystallization, so that the present Javanese culture is the complexity of heterogeneous western and traditional elements (Anderson 2000: 42-43).

Conceptions of power in the eyes of modern Europe can be summed up (this is done to help clarify ideas about the power of Java, so compared to the European concept or west) in four points: First, power is abstract (in the sense of finite or absent); second, sources of power are heterogeneous; third, the accumulation of power has no inherent boundaries; fourth, power is ambiguous (Anderson, 2000: 43-46). The conception of Java power applies vice versa from what is described by the 
concept of Europe, the conception of Javanese power according to Benedict R.OG. Anderson (2000: 47-50)

First, power is concrete. Power is a real thing, independent of those who may use it, power is not a theoretical postulate but is an existential reality. Power is an invisible, mysterious, divine energy that nourishes the universe. Power is manifest to every aspect of nature, rocks, trees, clouds. In Javanese traditional thought there is no strict separation between living and non-living things, because all are sustained by the same invisible power. Second, power is homogeneous. It follows the conception that all power is of the same kind and originating from the same source, power in the hands of one individual or group is the same as that which is in the hands of the individual and the other.

Third, the amount of power in the universe is constant. In Javanese view, the universe is neither developing nor shrinking, the total amount of power in it is always fixed. Power alone exists, not a product of organization, wealth, weaponry or anything else. The overall quantity does not change, although the distribution of power within the universe may vary. Fourth, power does not question validity. All power is derived from a single, homogeneous source of power, overcoming good-bad questions, for Javanese thought there is no question of questioning claims to rule on the basis of different sources of power. Power is not valid or invalid, that power exists.

According to Javanese culture, power is gained by the ascetic events and practices of yoga, such as fasting, walking without sleep, meditation, and not having sex in a given period of time, also obtained by holding royal ceremonies involving many people, objects containing strength, and symbols that contain mystical insights. Another way is to collect objects, like a dagger, gamelan, the carriage, the umbrella greatness, or goods heirloom other, or those perceived to have supernatural powers (kesakten), clownish, eunuchs, dwarfs, clairvoyant, healer, rishi or people who are considered to have advantages (Surbakti, 1992: 83).

Power in Javanese culture is identified by the following signs; The self-centered (in the ascetic), absorbing the power from the outside (the claim of the incarnation of the gods), focusing in itself contradictory matters of the ability to concentrate contradictory things within himself, such as sex (male and women), thought (nationalism, communism, nasakom), religion (Islam, Christian, Hindu, Budha, Beliefs), and class (military, party, region). As well as the revelation (devine radiance), is believed to be able to move, displacement revelation usually marks the waning or the fall of a dynasty or regime, the presence of power everyday can be seen on the faces of those in power, namely the presence or absence of light (cassia) on the face of the mighty (Surbakti, 1992: 83).

Power also has social features that include fertility, prosperity, stability and seclusion. Fertility can be seen from the number of descendants and grandchildren of the ruler, prosperity can be seen in the daily life of members of the community such as ensuring basic needs, stability describes order and peace in society, while the glory based on the greatness and glory of a kingdom or country is marked by the number Head of government or head of a foreign country visiting the country (Surbakti, 1992: 83).

Outlook Javanese life is linkage between theory and practical eventually leads to true wisdom, the theory for the Javanese is contemplation of the macrocosm to understand the life that eventually led to the horoscope (logbook result contemplation) and divination, and make the king is the center of the cosmos and the center of power (Kresna, 2013: 171-173). Leadership in Javanese culture is also manifested in the form of Brata feet; Namely the eight actions, the character, the main character that must be 
held by a leader consisting of earth, sun, fire, samudara, sky, wind, moon, stars (Hudaya, 2013: 3-4). Loyalty to leaders in Javanese culture is very important because it is based on Javanese norms dominated by loyalty, obedience, devotion and sacrifice (Sapto, 2015: 154).

Power in Javanese culture is divided into three classes; kings, aristocracy, subjects, the king and gentry status is the status of inherited and not acquired by certain business or obtained (Arimi, 2008: 7). The current understanding of Javanese power is still firmly attached to Kraton Kasunanan and Mangkunegaraan Surakarta and Kraton Kasultanan and Pakualaman Yogyakarta (Suyanto, 2005: 207). Although, there are some Javanese excluded from future hindu caste system (untouchables) and are not included in the three groups. They are unique because of their diversity of characters that retain animistic dynamism -Hindu Buddhist heritage and consider themselves Muslims first examples of Islam Kalang in Kendal regency, Central Java (Kholik, 2013: 117-118). The acculturation of Islam and Javanese culture can be seen from the physical (tombstones, architecture, sculpture), the celebration of the great days of Islam, the literary arts and the wayang art and the Islamic values that alter Javanese culture (Aziz, 2013: 254; 273).

The relevance of the use of theory and the definition of Javanese culture in this study is intended as a material comparison with Lampung culture. The Javanese as the largest population in Indonesia and spread throughout the province in Indonesia certainly have an influence on local culture in other areas. In the context of Lampung, which mostly come from the land of Java through the concept of transmigration, certainly affect the local culture in Lampung. An explanation of the concept of Javanese culture in this chapter to describe the elements of the similarities and differences with Lampung concept "Pesenggiri Piil" which will further clarify the concept of Piil Pesenggiri characterizes itself.

\section{Culture Society of Lampung}

The people of Lampung also have a local culture that is held up to the present time. Lampung culture has been recognized as one of the special culture, because Lampung is one of the few cultures in Indonesia that has its own script, so that the culture of Lampung has a high cultural value. Script Lampung consists of 20 characters that consist of letters $k a, g a, n g a$, $p a, b a, m a, t a, d a, n a, c a, j a$, his, yes, a, la, ra, sa, wa, $h a, g h a$, and there are 11 signs or child letters, and 5 symbols of punctuation (Abdullah, 2008: 14-15). Iskandar Syah (1999: 5) argues that:

“The people of Lampung are a plural society consisting of various ethnic groups, each of which has different backgrounds. The Lampung community is divided into two groups of Nation Tribes, namely the original Tribe and Tribe of the Nation. Indigenous tribes of Lampung tribe who inhabited the Lampung region since centuries ago while the tribe of immigrants, especially transmigrants from outside the area of Lampung."

Lampung people's heritage is a cultural one Piil Pesenggiri which is a philosophy of life Lampung. Fachruddin and Haryadi (1996: 3) points out, culture area of Lampung is the view or philosophy of life Lampung people, known as Piil Pesenggiri philosophy. Philosophy Piil Pesinggiri are the points of philosophy that comes from the books of customs adopted by the people of Lampung, consisting of: Piil Pesenggiri (Principle of Honor), Bejuluk Adek (Principles of Success), Nemui Nyimah (Principle Award), Nengah Nyappur (Principle equations), Sakai Sambaian (Principles of Cooperation).

Lampungethniccommunity consists of two sub-ethnicity, namely Lampung Pepadun sub ethnicity and ethnic sub Saibatin. Lampung people Pepadun or Saibatin, both have the same 
philosophy of life that is Piil Pesenggiri which is one of the culture of Lampung. Iskandar Syah (1999: 20-22) suggests that:

"Pepadun habitual Lampung society, marked by ceremonies customary decision-degree position by using a tool called the ceremony Pepadun. Pepadun habitual Lampung people divided into several groups, namely: Abung Siwo Megou, include: Buay Nunyai, Buay Unyi, Buay Nuban, Buay Subing, Buay Kunang, Buay Selagi, Buay Selaga, Buay Tuha, Buay Nyerupa. Megou Pak Tulang Bawang, include: Buay Balau, Buay Umpu, Buay Tegamoan, Buay Aji. Buay Lima (Way Kanan / Sungkai), includes: Buay Barasakti, Buay Semenguk, Buay Baradatu, Buay Pemuko, Buay Bahugo. Pubian telu suku, include: Buay Manyarakat, Buay Tambapupus, Buay Bukujadi. Saibatin habitual Lampung people also called Peminggir society because they generally reside in coastal areas or coastal differ from those pepadun which generally reside in the countryside. Communities including Saibatin is Peminggir Melinting/Rajabasa, Peminggir bay, Peminggir Semaka, Peminggir Skalaberak, Ranau, Ogan and Kayu Agung."

Piil Pesenggiri Lampung is a people's heritage, which is a philosophy of life of people of Lampung. Piil Pesenggiri is an idea for a community of Lampung, Piil Pesenggiri is the principle and self-esteem, Piil is the principle Pesenggiri, Pesenggiri is self-esteem, meaning elements pesenggiri are principles that if that principle is upheld then self esteem will naturally good or prestige a person will be good or high by doing so (Facruddin and Haryadi, 1996: 35).

Piil Pesenggiri literally means action or human temperament sublime in value and significance, therefore exemplary and never to be denied. While in the official literature documents, Piil Pesenggiri interpreted as everything related to self-esteem, behavior and attitudes which must maintain and uphold the good name, dignity of the individual and group. Piil Pesenggiri totality implies highminded, have a sense of shame, self-esteem, friendly, outgoing, mutual help and a big name (Syah, 1999: 24-25).

The term Piil Pesenggiri probably derived from "Piil" in Arabic, which means actions or mannerisms and words "Pesenggiri" that the hero of popular opposition Bali north against troops Majapahit led by Arya Damar, thus Piil Pesenggiri mean temperament is not that hard do not want to resign against acts of violence, which are especially concerned with the offending good name of descent or personal honor and relatives (Hadikusuma, 1989: 119).

If someone wants to have self-esteem, then be smart to respect others (Nemui Nyimah / Bepudak Waya), be smart associate (Nengah Nyappur / Tetengah Tetangah), diligent work to achieve and prestige (named Adek / Khopkhama Delom Bekekhja), that principle and that is selfesteem (Bupiil Bupesenggiri) (Facruddin and Haryadi, 1996: 19).

Piil Pesenggiri Philosophy to Life of Lampung has several elements, which are elements of this Pesenggiri Piil itemized by Facruddin and Haryadi (1996: 22 to 26.35), consisting of Nemui Nyimah, Nengah Nyappur, Sakai Sambayan, Juluk Adok and Piil Pesenggiri.

Nemui Nyimah interpreted as a courtesy. Nemui nyimah etymology is honoring guests and act sweet face, both merged into "courtesy" so the manners described elements into the points in more detail. In honor of the elements, besides guests then someone should behave well, Lampung people typically present these kinds of food and drinks, so shrouded in principle, this is Nemui Nyimah ownership. This makes it possible to treat the guest, in other words a person must be skilled, earning, in 
other words producing. Manners as described mentioned above is a skill, production and income as well as ownership, is intended as an attempt to meet the many human intent, namely as the giver. As it is believed that the giver will be nobler than the recipient. Thus, the courtesy here in addition to being interpreted as manners also has a social meaning as follows good behavior, knowledgeable, skilled, earning, producing and serving the community.

Nengah Nyappur interpreted as jaunty. Nengah Nyappur word itself is also capable of plunging kegelanggang meaningful. Of course with polite capitalize in the sense of understanding all rights and duties. Polite in the sense ready to be the giver, then someone as demanded by nengah nyappur, must be a person who has an upbeat, has a high tolerance, but not forget the principles that must be held in life as identity. Thus, a person is required to be careful, considerate, principled, rich in ideas, aspiring, able to communicate, able to compete

Sakai Sambayan interpreted as helping. Sakai Sambayan more accurately translated into unity and consensus. So please help here has a very broad meaning, the meaning demanded by Piil Pesenggiri contained in Sambayan Sakai said. Please help in sakai sambayan version will mean mutual cooperation. Thus, the definition of help is very broad, among others, able to become unifier, have capital (capital), have the means and infrastructure, able to cooperate, reliable, able to take advantage.

Juluk Adok means a degree or prestige. Someone is required to work hard to achieve results to meet the needs of life both for himself and for others. Prestige is juluk Adok is something that is automatically available whenever a person has reached the maximum work. So that hard work and job performance cover the following scope to understand the needs of self and community needs, able to absorb leadership skills, deserve to be a role model.
Piil Pesenggiri is an ideal condition for a community of Lampung, Piil Pesenggiri is the principle and self-esteem, Piil is the principle Pesenggiri, Pesenggiri is self-esteem, meaning elements Pesenggiri are principles that if that principle is upheld then dignity itself Prestige will be good or someone will be good or high to do

Piil Pesenggiri elements also include scope, as follows ; juluk adok, juluk adok is customary title, etymologically composed of words and juluk adok each of which has a meaning. Juluk adok is the name (customary title) for women and men while he is still young or teenagers or unmarried, and juluk adok meaningful women or man who is married. Still dealing with juluk adok is Inai and Amai. Henna is a nickname for a married woman, by the family of the husband or male. While Amai is nickname to a man who had married wives from the family (Hadikusuma, 1989: 120-123).

The concrete form of Nemui Nyimah in public life today is more accurately translated as the nature of social awareness and a sense of solidarity. Nengah Nyappur, nengah derived from the noun and the verb "nengah" means at the center, while the "Nyappur" is derived from the noun Cappur be a noun Nyappur means frosted or mingle, run private literally interpreted as a gesture like to hang out, like friends and tolerance. Nengah Nyappur Lampung illustrates that members of the community with the provision of a sense of family and accompanied with an attitude like to hang out and make friends with anyone who does not distinguish between religion and levels, gregarious and friendly attitude pose a curious attitude, willing to listen and react and responsiveness. Sambayan Sakai, Sakai means giving something to a person or group of people shaped objects and services of economic value, but expect a reply. While Sambayan means giving something to a person or group of objects shaped and special services or do not expect a reply. Sakai Sambayan means of 
mutual cooperation and mutual help, means understanding the Sakai Sambayan is essentially showing a sense of participation and solidarity in the community to activities or obligations that must be done (Hadikusuma, 1989: 120123).

\section{Power in Lampung Culture}

In the context of Lampung as local ethnic community living in Lampung province, there is a problem that the ethnic Lampung underappreciated by immigrant communities (ethnic beyond Lampung). Statistically where the original Ethnic Lampung (both Pesisir and Pubian) annually stagnated, the Central Bureau of Statistics Lampung (2016) write that the number of ethnic Lampung, only $15 \%$ of the entire population in Lampung.

Lampung people are often given the stigma that their actions were often out of context Piil Pesenggiri, basically Piil Pesenggiri positive meaning, but to the community outside of Lampung population, into meaningful negative. Piil Psesenggiri changed its form as a way of Lampung people and resistance against inequality against migrants, as a way to recognize and reward as lokal. Lampung community identity is lose inseparable from the swift entrants, and make Lampung as the area of migration (also destinations transmigration) and contributes to the position Lampung people. The dominance of the stronger comers along with local naming patterns that have developed since the era of transmigration, according to their areas of origin in the name of the island of Java. The newcomers became more dominant, especially in economic, land tenure, and do not position themselves as immigrants (Sinaga, 2014: 110111).

Since the era of direct local elections, many public figures Lampung, both traditional leaders, leaders Lampung with strong financial capital, or a person appointed as a non Lampung customary brother (juluk adok) by Lampung people are struggling in the elections (election). An equation which became the model until now is the figure that appears Lampung always held the Java community leaders, so that the model of the elections in Lampung always the same pattern, namely Lampung-Java combination. Candidates for Governor, Mayor, The Regent is a man Lampung and prospective Alternates are Javanese, or otherwise a combination of Java and Lampung.

Power in the culture of Lampung is prestige (awards) as a manifestation of Piil Pesenggiri, so forward as a candidate in the election of regional heads is a great pride, regardless of winning or losing in the electoral arena. All the areas that hold the elections simultaneously in Lampung Province in December 2015 (8 areas) and volume two simultaneous local elections in February 2017 (5 regions) then there is always the Lampung ethnic advanced, either as a candidate for regent / mayor and deputy regent / mayor.

Philosophical values of culture of Lampung, in which there are ethical values, moral, spiritual values of material and non-material which is interpreted in the social and cultural systems, works to build awareness of the moral glue of unity nation, and adhesives in social life, cultural, economic and political well (Nurdin, 2009: 9495). Piil Pesenggiri in this case is the glue for the candidates who will advance in the election of regional heads, so that conflicts between candidates when the election is finished rare, although there usually is in the realm of pemiih or sympathizers of the prospective head region, never frontal among the candidates.

Process marginalizing the local population as a result of migration Lampung in Lampung causes people to be a minority in the midst of the cultural heterogeneity of migrants. Faced with this marginalization Lampung people build and evoke tradition (a tradition of invention) in order to strengthen the collective consciousness through the interpretation Piil Pesenggiri (dignity) are reproduced and 
articulated as a representation of identity (Irianto, 2011: 140). The representation of this identity by author manifested in local elections, leaders and people of Lampung always comes within the context of power at local elections. Characteristics of regional head and deputy regional head (neither the Governor, the Mayor and Regent) based on ethnicity in Lampung, composed of 15 ethnic Lampung, 10 were ethnic Javanese, the remaining 2 other ethnic people (Irianto, 2011: 146).

Lampung people in terms of political participation, are very high to be involved as a candidate for regional head and deputy head of the region, but participation in the airport inversely. In the perspective of public services, culture Piil Pesenggiri not too upheld by bureaucrats or street level bureaucracy in charge of serving the community. Pairulsyah (2013: 173-176) showed that the quality of service needs to be scaled back because of the principles of the local culture of Lampung 'Piil Pesenggiri' not too deeply internalized by bureaucrats.

\section{Culture and Mystical Politics}

References Lampung community life in the context of grabbing power through elections that represented the local elections, especially during this period of 2005 to 2015 and then, becomes a fortress in the election dispute resolution. Bawaslu RI and the National Police in 2015 and issued a statement that Lampung is prone province in the implementation of local elections because of the potential conflict.

In practice the election battle, the principle piil pesenggiri unused, if the fight is still associated with family relationships. Family battle can be seen in the case against Syacroedin Alzier in Lampung Governor Election 2008, Alzier against Heri Sembodo and Pileg Dewi Arum in 2014, and several cases of election in the regency / municipal span of 2005 to 2015.

Javanese cultural influence is also felt in the cultural context of Lampung, animism and dynamism that believe in the occult and mysticism also occur in the implementation of the election. Some of the candidates dies before the implementation of the election in the area, and some communities in Lampung linking them with things occult and mystical. Javanese mysticism is the result of core starch sikretisme various religious teachings and traditions of communal thousands of years ago, which has many of the elements of which the political leadership (Endaswara in Maristiyawan, 2015: 41). Mystical-spiritual experience in understanding the existence itself is part of the way of life of Java (Krishna, 2013: 170).

Some examples of cases, Zubaedah that have been defined as candidates by the Election Commission of North Lampung who died of illness at the North Lampung Local Election in 2013, and also Paryadi Deputy Regent of North Lampung elected in the election in 2013 is paired with elected Regent Agung Ilmu Mangku Negara, can not be elected for long illness, which eventually died. Another case is a candidate for Vice Regent of East Lampung, party PKS, which is paired with the incumbent Regent Erwin Arifin also died of illness before the implementation of the 2015 East Lampung local election, so Erwin advanced Arifin canceled because her partner died. Mesuji trace backward in the elections of 2011, Tasks executor Mesuji Regent; Ruswandi also died while desirous forward as a candidate regent in Mesuji,the latter case is the death of Vice Regent Mesuji Ismail Ishak, because of strange pain when desirous of advancing into the Regent on Mesuji Local election 2017 (Source: adapted from some secondary data in local print media Lampung).

Associated with the death of Ismail Ishak, Adam Ishak who is the younger brother of Ismail Ishak forward as a candidate Vice Regent Mesuji paired with Febrina Lesisie on Mesuji Local Election 2017 have their own opinions. Adam Ishak told, Ismail Ishak's illness has 
lasted nearly two months, his brother Adam said that disease associated with things mystical. More Adam recounts:

"Initially, frequent headaches, and every check-up doctor said there is no disease, check-ups several times a disease was not found. Once combined doctors and clerics check Ismail Ishak, then they perform the operation, and from my brother's neck and the rope pocong needle out, it was about 1.5 months ago. After the odd items was issued, then a lot of mucus from the neck and spread to the head. Makanya then performed brain surgery to remove mucus, about a week ago in Jakarta Islamic Hospital" (Tribune Lampung; Sunday, October 16, 2016, p 7).

Lexi Frenzi, Ismail Ishak's son declared that the doctor did not give clear information about his disease diagnosis, he added the deceased did not have a history of severe disease during the time, fever is also rare. Lexi said his father's health condition began to decline dramatically since two months ago. It was the days before registration of prospective head region. Ismail himself predicted candidates forward into Mesuji, side by side with Iskandar Maliki as his deputy. (Tribune Lampung; Sunday, October 16, 2016, p 1). In connection with sick father, Lexi Frenzi states;

\begin{abstract}
"the pain is strange, always changing. Initially stomach pain. Then treat turned into a headache, and then changed again to chest pain "(Tribune Lampung, 16/10-2016, p 1).
\end{abstract}

\section{Conclusion}

Political Science main orientation is to gain power in the context of western thought and the individual must be rational, ways swept to power in the western conception through several concepts; the influence, persuasion or rational argument, manipulation, coercion, physical and psychological pressure and authority. Powers also has six dimensions, potential and actual, positive and negative, consensus and coercion, office and personal, implicit and explicit, direct and indirect.

Javanese culture as a representation of Indonesia, conceptions of power is different from the western conception. In the eyes of modern Europe can be summarized four points: first; power is abstract (in the sense of limited or non-existent), second; power sources are heterogeneous, third; the accumulation of power does not have inherent limitations, fourth; power is ambiguous. Java powers prevailing conception opposite of what was presented by the European concept, the conception of power that is Java, there are four points; power is concrete, power is homogeneous, the amount of power in the universe is constant, power is not questioned the validity. How to gain power in Javanese culture in practice is irrational and mystical.

Lampung culture itself has a reference in the life included in the conception of power, namely the principle of Piil Pesenggiri (Principle of Honor), Bejuluk Adek (Principles of Success), Nemui Nyimah (Principle Award), Nengah Nyappur (Principle of Equality), Sakai Sambaian (Principles of Cooperation) are is defined as behavior; courtesy / respect, jaunty, helping, working hard to get a degree, and self-esteem.

Lampung culture in the context of a power struggle exists only in the level of concept which in practice is different, especially in the implementation of local elections be used. Power in the cultural views of Lampung be one piil esteem wherever possible be won. Most people still believe Lampung mystical things as part of their lives. This mystical things have in common with the Javanese culture is also thick with mystical.

In some of the positive side of Lampung local culture in the context of local wisdom as a 
form of local diranah autonomous power, can be used as a foothold in a democracy, with five basic principle (piil pesenggiri), but in practice some of the principles it becomes lost.

\section{References}

Abdullah. (2008). Wawasan Bahasa dan Aksara Lampung. Lampung: Penerbit Buana Cipta.

Anderson, B. (2000). Kuasa Kata, Jelajah BudayaBudaya Politik di Indonesia. Yogyakarta: Mata Bangsa.

Arimi, S. (2008). Pergeseran Kekuasaan Bangsawan Jawa Indonesia: Sebuah Analisis Wacana Kritis. Jurnal Masyarakat dan Budaya, 10(2), 1-22.

Aziz, D. K. (2013). Akulturasi Islam dan Budaya Jawa. Jurnal Fikrah, 1(2), 253-286.

Budiarjo, M. (2008). Dasar - Dasar Ilmu Politik. Jakarta: PT Gramedia Pustaka Utama.

Dahl, R. (1985). Analisa Politik Modern. Jakarta: Bina Aksara.

Darmawan, I. (2015). Mengenal Ilmu Politik. Jakarta: PT Kompas Media Nusantara.

Dinas Pemuda Olahraga Kebudayaan dan Pariwisata Kabupaten Way Kanan dengan Lembaga Penelitian Universitas Lampung. (2014). Konsepsi Piil Pesenggiri Menurut Masyarakat Adat Lampung Way Kanan di Kabupaten Way Kanan (Sebuah pendekatan Discourse Analysis). Lampung: Aura Publishing.

Fachruddin \& Haryadi. (1996). Falsafah Piil Pesenggiri Sebagai Norma Tatakrama Kehidupan Sosial Masyarakat Lampung. Bandar Lampung: CV Arian Jaya.

Hadikusuma, H. (1989). Masyarakat dan Adat Budaya Lampung. Bandung: Mandar Maju.

Heywood, A. (2004). Political Theory, an Introduction. New York: Palgrave Macmillan Ltd.

Hudaya, Z. A. \& Sigit W. D. N. (2013). Kearifan Lokal Budaya Jawa sebagai Basis Model Kepemimpinan yang Efektif. Jurnal
Manajemen. Retrieved from http://jp.feb. unsoed.ac.id/index.php/sca-1/article/ viewFile/222/227

Irianto, S. \& Risma M. (2011). Piil Pesenggiri: Modal Budaya dan Strategi Identitas Ulun Lampung. Jurnal Makara, Sosial Humaniora 15(2), 140-150.

Kholik, A. (2015). Islam Kalang: Politik Identitas Sub Etnis Jawa. Jurnal Harmoni Multikultural \& Multireligius, 12(1), 116-129.

Kresna, A. A. (2013). Demokrasi dan Kekuasaan dalam Pandangan Hidup Orang Jawa. Jurnal Ultima Humaniora 1(2), 169-179.

Maristiyawan, E., Ramdhoni M. H., Sulaiman N.,Hertanto. (2014). Keyakinan terhadap Mistik Jawa dan Kepemimpinan Politik Menurut Kajian Ketua-Ketua Kampung di Kecamatan Batanghari Kabupaten Lampung Timur, Provinsi Lampung, Indonesia. International Journal of Malay World and Civilisation (Iman), 3(3), 41-48. Nurdin A. F. (2009). Integralisme Islam dan Nilai-Nilai Filosofis Budaya Lokal pada Pembangunan Propinsi Lampung. Jurnal UNISIA, 32(7), 81-97.

Pairulsyah. (2013). Kualitas Pelayanan Publik Samsat Lampung dalam Perspektif Budaya Piil Pesenggiri. Fiat Justitia Jurnal Ilmu Hukum, 7(2), 168-180.

Sapto, A. (2013). Pelestarian Kekuasaan pada Masa Mataram Islam: Sebha Jaminan Loyalitas Daerah Kepada Pusat. Jurnal Sejarah dan Budaya, 9(2), 153-161.

Schmandt, H. J. (2002). Filsafat Politik, Kajian Historis dari zaman Yunani Kuno sampai Zaman Modern. Yogyakarta: Pustaka Pelajar.

Sinaga, R. M. (2014). Revitalisasi Tradisi: Strategi Mengubah Stigma, Kajian Piil Pesenggiri dalam Budaya Lampung. Jurnal Masyarakat Indonesia, 40(1), 109121.

Sinaga, R. M. (2014). Revitalization of Tradition: a Changing Stigma, Study of Culture Piil Pesenggiri Pesenggiri in 
Lampung. Dissertation Anthropology Studies Program, University of Indonesia. Sugiyono. (2006). Metode Penelitian Kuantitatif, Kualitatif dan RED. Bandung: Alfabeta. Surbakti, R. (1992). Memahami Ilmu Politik. Jakarta: Gramedia Widya Sarana.

Suyanto, I. \& Gunawan. (2005). Faham

Kekuasaan Jawa: Pandangan Elit
Keraton Surakarta dan Yogyakarta. Jurnal Antropologi Indonesia, 29(2), 207-218.

Syah, I. (1999). Sejarah Kebudayaan Lampung. Lampung: Universitas Lampung.

Tribune Lampung, Sunday, October 16, 2016. Ismail Drop Ahead of the Elections, Vice Regent Mesuji Died, Family Think of Strange Disease Ismail Ishak, 1-7. 